The Geographical Journal of Nepal, Vol. 7, 2009: 53-60

\title{
Cultural Practices and Environment along the Bishnumati River in Kathmandu
}

\author{
Shobha Shrestha \\ Lecturer \\ Central Department of Geography, Tribhuvan University \\ shova216@.gmail.com
}

\begin{abstract}
The Bishnumati River is one of the major sources of water in Kathmandu city for domestic and agricultural uses. But the quality of the river environment has been degraded seriously since the last few years. This paper is an attempt to explore environmental condition along the Bishnumati River with specific focus on human activities, perception and institutional efforts in dealing with the river environment. Based on field observation, household survey, and key informant survey in eight segments along the river stretch from the city periphery to down town, the information acquired indicate that human activities related to environmentally sensitive phenomena were very much dominant in degrading the river environment. The local inhabitants were aware of the river environmental conservation. The local public agencies were however not seriousness in implementing the waste management activities, but instead they practiced environmentally sensitive activities at the riverbanks. Efforts at both local community and public agencies levels are most warranted to protect the Bishnumati river environment from further degradation.
\end{abstract}

\section{Introduction}

Human activities along the river banks have brought about changes in environmental condition, among which polluting water, dumping wastes, and sand and stone quarrying are the most obvious in major cities of Nepal. Rapid growth of urban population and mass rural to urban migration are some of the causes for such adverse impacts on environmental condition. Urban Kathmandu is no exception. The Bishnumati River is one of the major tributaries of the Bagmati River and also major sources of water for urban Kathmandu. It flows from the north to south through heavily populated core area. The river has important cultural and religious significance for the inhabitants living at its nearby areas. In spite of the fact that the Bishnumati has been indispensable for the socio-cultural practices of the people, the river is getting polluted and 
its original value is being shaded off by the degraded environment. Available studies indicate that almost all the rivers traversing Kathmandu valley have attained high degree of pollution (Khatri, 1986; MOPE, 1999; UNEP, 2002; Basnet, 2005; Baidya, 2005; Tuladhar, 2006; and Shakya, 2007). Both the population and economy of the valley have grown at the expense of natural and cultural degradations. In recent years, the cost of environmental degradation has overshadowed the fruits of wealth and development.

This paper is an attempt to explore the factors responsible for environmental degradation along the Bishnumati River in Kathmandu, with specific focus on the spatial pattern of human activities, the relationship between cultural practice and environmental awareness of the inhabitants nearby the river and people's perception on effectiveness of public authorities on river environment conservation.

\section{Methodology}

The study has been based mainly on field survey data. First, a-50 metres buffer zones at both sides of the Bishnumati river were defined and the stretch of the river was divided into eight segments (Fig. 1: Table 1). Stratified random sampling was applied for selecting the localities, representing from each segment. Secondly, structured field protocol and checklist were used to record data through field visit. All the phenomena related to nature and human activities were observed thoroughly in all segments and carefully noted down. Map (1: 2 000) of the study area was used to verify information of those phenomena. Observation of the phenomena was performed at critical points throughout the day in the morning, the mid-day and the evening. Global Positioning System (GPS) was used to verify

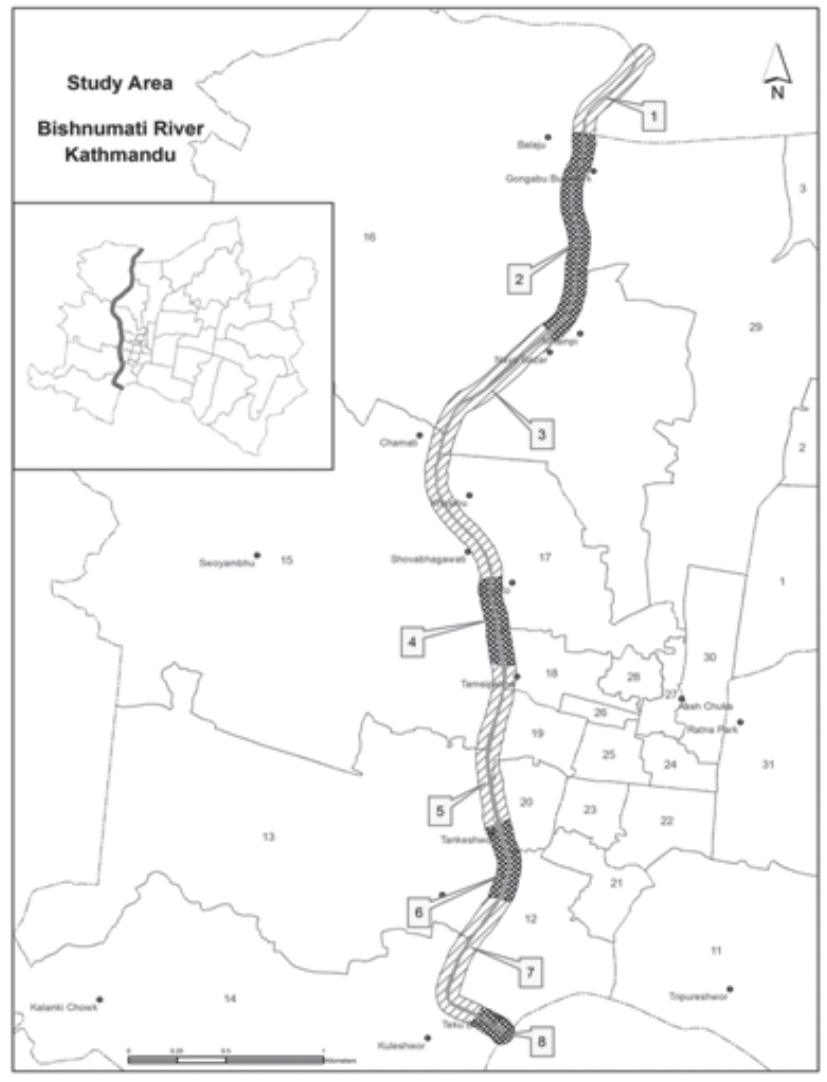

Figure 1: Location of the Study Area geographic locations and the social and economic activities therein. Photographs of the remarkable phenomena were also taken.

Questionnaire survey was carried out to a total of 32 (4 from each segment) sampled people of those localities from whom data on the cultural practices and perception of environment 
conservation were acquired through administering questionnaire forms. In addition, interview with a total of 8 key informants comprising local institutional personnel was carried out to obtain data on socio-cultural values of the river, based on the prepared checklist.

Archive digital data and analogue map 1:2 000 of the study area produced by the Department of Urban Development and Building Construction (DUDBC) and Kathmandu Metropolitan City (KMC) were used for digital data processing and analysis. Likewise, satellite imagery data was also acquired from Google Earth. Digital database has been prepared by using GIS software like ArcView and ArcGIS. Data were also obtained from the secondary sources such as reports, population census.

The stretch of the study area covers 67.42 hectare along the Bishnumati river from the Balaju locality in the north to the confluence of the Bagmati river at the Teku locality in the south. This comprises parts of ten wards of Kathmandu Metropolitan city.

Fifty metres at both sides of the Bishnumati river was determined in order to obtain their environmental condition. The bridges along the river were considered as base stations and the section from one bridge to another was regarded as segment. Thus, a total of eight segments along the study stretch were obtained.

Table 1 describes each segment and its major localities, and area coverage. The area of the segments ranges from 18.94 hectare, the largest (Segment III) to 2.38 hectare, the smallest (Segment VIII). Thus the area coverage varies remarkably among the segments.

Table 1: Description of the segments of the study area

\begin{tabular}{clcc}
\hline Segment & Major localities & Area (ha) & Percent \\
\hline I & Balaju, Gongabu & 3.25 & 4.82 \\
II & Balaju Industrial Estate, Mhaypi & 12.55 & 18.61 \\
III & Nayabazaar, Chamati, Shovabhagawati & 18.94 & 28.10 \\
IV & Dhalko, Bijeshwori & 5.60 & 8.31 \\
V & Maru, Tankeshwor, Tahachal & 10.40 & 15.43 \\
VI & Kalimati, Teku & 5.22 & 7.74 \\
VII & Kuleshwor, Teku & 9.08 & 13.46 \\
VIII & Kuleshwor, Tekudovan, Sanepa & 2.38 & 3.52 \\
\hline & Total & 67.42 & 100.00 \\
\hline
\end{tabular}

Source: Calculated from map/satellite image, GoogleEarth (2006)

\section{The Bishnumati River Stretch - Environmental and Social Settings}

The Bishnumati river is one of the major tributaries of the Bagmati river. It originates from the Shivapuri hill at above 2,481 $\mathrm{m}$ in the north of Kathmandu valley and merges with the Bagmati river at the Teku confluence travelling over $17 \mathrm{~km}$. It has six feeder tributaries namely, the 
Shivapuri khola, Shangla khola, Mahadev khola, Samakhusi khola, Bhachakusi khola and Manamati khola, and flows through densely populated core areas of the city. Its upstream area is thinly populated. Roads have been constructed along the both sides of the river and agriculture and forest are almost nonexistent. The densely settled areas at nearby of the river are mostly of slums and the river banks in many pocket areas consist of squatter settlements. According to the 2001 census, though the segments 2, 4 and 7 have the largest population, the segments 4 and 5 have the highest population density.

Table 2: Land use categories of the Bishnumati study stretch

\begin{tabular}{lrr}
\hline Land use & Area (ha) & Percent \\
\hline Built up & 22.00 & 32.63 \\
Cultivation & 6.86 & 10.18 \\
Heritage sites & 0.47 & 0.69 \\
Institutional & 0.69 & 1.02 \\
Open area & 9.97 & 14.79 \\
River course & 9.06 & 13.43 \\
River bank & 11.06 & 16.40 \\
Road & 6.91 & 10.25 \\
Vegetation & 0.41 & 0.61 \\
Total area & 67.42 & 100.00 \\
\hline
\end{tabular}

The analysis of the archived satellite imagery (2006) together with field verification indicates

Source: Satellite Imagery 2006, Google Earth and Field Survey 2007/08

that there are nine land use categories (Table 2). Dense urban built up is the largest land use category with nearly 33 per cent of the total study river stretch, followed by river bank and open area. The vegetation coverage is the least with 0.61 per cent, which signifies the poor condition of greenery and environment. Cultivation coverage is mainly characterized by intensive vegetable farming. Table 2 shows that the river stretch is predominantly covered by the human activities and their impacts.

\section{Cultural Habits and Environmental Awareness}

The study area of the Bishnumati river stretch consists of two principal activities, viz. natural and cultural or human. The activities along the stretch were recorded in terms of frequency. Table 3 indicates that of the total activities/frequencies (f) of 207, the natural factors including river bank cutting, erosion and river course change cover only 4.83 percent, whereas human factors comprising 11 types of activities share the rest, over 95 per cent. So, the impacts of the natural factors seem less visible compared to the human cultural factors regarding river environment.

Among the natural factors, bank cutting is the largest activity. Of the human and cultural factors, three activities like industry and workshop related activities, solid waste dumping, and scrapped metals are the most important activities in terms of frequency. Of these, industry and workshop related activity is the largest, sharing 19.32 per cent (Table 3). It is interesting to note that sand quarrying has been the least activity, despite close to the city and rapidly increasing construction of buildings in the city. More importantly, most of the banks of the river are filled with solid wastes, which do not allow places for sand extraction. 
Cultural Practices and Environment along the Bishnumati River in Kathmandu -Shobha Shrestha

Table 3: Natural and cultural activities in the Bishnumati river stretch

\begin{tabular}{llllll} 
& & & & Total (f) $=207$ \\
\hline Activities - Natural & $f$ & $\%$ & Activities - Human and Cultural & $f$ & $\%$ \\
1. Erosion & 1 & 0.48 & 1. Open defecation & 17 & 8.21 \\
2. Course change & 3 & 1.45 & 2. Land encroachment/squatted & 11 & 5.31 \\
3. Bank cutting & 6 & 2.90 & 3. Slaughtering/animal shed & 13 & 6.28 \\
\cline { 1 - 2 } Subtotal & 10 & 4.83 & 4. Industry and workshop related activities & 40 & 19.32 \\
& & & 5. Cremation & 10 & 4.83 \\
& & & 6. Agriculture & 13 & 6.28 \\
& & 7. Construction debris & 15 & 7.25 \\
& & 8. Scrapped metals & 26 & 12.56 \\
& & 9. Extraction/quarry & 4 & 1.93 \\
& & 10. Solid waste dumping & 29 & 14.01 \\
& & 11. Direct sewerage disposal & 24 & 11.59 \\
\cline { 3 - 5 } & & Subtotal & 197 & 95.17 \\
\hline
\end{tabular}

Source: Field Survey, 2007/08

Table 4 shows the activities by segment. In terms of frequency, segment II has the highest concentration of environmentally sensitive activities related to human and natural factors, whereas segment VIII has the least of those activities. The former lies nearby city core and the latter at the periphery of the city. Industry and workshop related activity is highest in segments II and V. Similarly activities like animal slaughtering, open defecation and land encroachment are also highly concentrated in segment V. Agricultural activity, mostly vegetable farming is comparably more in segment I. Cremation site is concentrated in segment IV where heritage sites are also located. The cremation sites are located near Shovabhagavati and Indrayani shrine sites. Direct disposal of urban sewer is common in all segments and likewise, sewerage outlets are also evenly distributed among the segments. As most of the institution and open space are found in segment VIII, the human activities is less than those in other segments. However, solid waste transfer station is located in this segment. The average number of activities is 26.

Table 4: Distribution of natural and human cultural activities by segments

\begin{tabular}{llrrrrrrrrr}
\hline Factors & Activities & \multicolumn{4}{c}{ Segments } & \multicolumn{3}{c}{ Total } \\
\cline { 3 - 9 } & & I & II & III & IV & V & VI & VII & VIII & \\
\hline 1. Natural & Erosion & 1 & 0 & 0 & 0 & 0 & 0 & 0 & 0 & 1 \\
factors & Course change & 0 & 1 & 0 & 1 & 0 & 0 & 0 & 1 & 3 \\
& Bank cutting & 1 & 2 & 0 & 1 & 1 & 0 & 1 & 0 & 6 \\
2. Cultural & Open defecations & 2 & 2 & 1 & 3 & 4 & 2 & 2 & 1 & 17 \\
& Land encroachment/squatted & 1 & 1 & 1 & 0 & 5 & 2 & 1 & 0 & 11 \\
& Slaughtering/animal shed & 0 & 2 & 0 & 2 & 1 & 5 & 2 & 1 & 13 \\
& Industry related activities & 4 & 7 & 5 & 5 & 7 & 5 & 4 & 2 & 40 \\
& Cremation & 0 & 0 & 1 & 5 & 1 & 1 & 1 & 1 & 10 \\
& Agriculture & 4 & 2 & 2 & 3 & 1 & 1 & 0 & 0 & 13 \\
& Construction debris & 2 & 3 & 2 & 2 & 2 & 2 & 1 & 1 & 15 \\
& Scrapped metals & 3 & 4 & 3 & 4 & 2 & 4 & 4 & 2 & 26 \\
& Extraction/ Quarry & 1 & 1 & 0 & 0 & 0 & 0 & 1 & 1 & 4 \\
& Solid waste dumping & 5 & 5 & 5 & 4 & 3 & 2 & 2 & 3 & 29 \\
& Direct sewerage disposal & 3 & 4 & 3 & 3 & 3 & 3 & 2 & 3 & 24 \\
\hline & Total & 27 & 34 & 22 & 33 & 25 & 26 & 21 & 16 & 207 \\
\hline & Source: Field Survey & $2007 / 08$ & & & &
\end{tabular}




\section{Environmental Knowledge and Practice}

Traditionally, when there were no local government authorities, three major practices for waste collection and management in use were:

- Burning: wastes mostly came from the field were burnt and the remains like ash was used for cleaning utensils and kitchen garden

- Composting: organic wastes from the kitchen and toilet were decayed for manure and used in the farm fields

- Burying: other wastes like non-degradable items were buried into the nearby field.

These indigenous practices are now not in practice. The field survey information indicates that the local people were aware of the degrading river environment, but at the same time they seemed to have practiced of dumping all types of wastes into the river. It was also found that they were aware of the health problems they were facing and particularly their children's poor health due to poor sanitation and polluted river environment. It is found that 80 per cent of the respondents of the nearby river dumped solid wastes directly into the river. Sewerage outlets of all houses end into the river. Thus, there existed a conflict between knowledge and practice, which might be due to lack of alternatives to be provided by the local development authorities. The responsible public agencies were also found not serious to collect wastes along the riverside. There were private groups being contracted out by the local public agencies were engaged in the collection of wastes on fee basis for which each household paid at least Rs 125 per month. It was also observed that neither authority nor local people could stop the people dumping wastes such as construction debris, animal remains, metal scrapping, etc in big volume into the riverbanks. There was little or no motivation among the local inhabitants in conserving their locale.

\section{Institutional Efforts and Public Perception}

Local authorities are found to have involved in various programs and projects related to urban environment management. KMC is a major local government agency that has a unit of Environment Management Department to care of environmental conservation of the city rivers, including the Bishnumati. Despite this, the local public agencies were themselves responsible directly and indirectly for deteriorating river environment. Locating solid waste transfer station and solid waste collection containers at the banks of the river, construction of public toilets nearby river, direct discharge of sewerage into the river, etc were some of the examples of malpractices for river environment degradation. According to the local people, development activities, mostly road construction along the riverbanks and institutionalization of waste collection and management which was previously done by the local people were major causes for the degradation of environment.

Various attempts have been made by the local government for the improvement of the environment of the Bishnumati river, but the perception of local inhabitants towards the local 
public institutions and municipalities was found not positive due to lack of seriousness in implementing those plans and programmes. Local people were also aware that the local government agencies would be responsible for river environment conservation. The local inhabitants argued that unless the local authorities felt themselves responsible for keeping up urban environment clean, they would not be able to enforce rules and regulations for the local people to do so. They strongly argued that the local authorities should bring programmes and coordinate with local people, community based organizations and non-government organizations for implementation of those programmes. They should also be responsible to provide rules and regulations and guidelines and follow the sincerely while implementing.

\section{Conclusion}

This paper dealt with the environmental condition of one of the main rivers - Bishnumati in Kathmandu, the capital and largest city of Nepal shows that degradation of the river environment is largely due to human activities and institutional malpractices. It shows that there is still open area of 20 per cent at the riverbank, which has provided space for dumping wastes of all types and other environmentally sensitive activities. This means that there is clearly lack of policies and programmes for conservation of the river environment. The local people were aware of their deteriorating river environment and health conditions, no efforts at household level were found to be made, nor at institution level. So, they had not alternatives but to pollute the river environment by dumping all wastes. Some of the pertinent measures suggested by the local inhabitants towards conservation of river environment were diversion of sewerage network, public participation on solid waste management and awareness raising activities,

It seems that the public authorities haven't given high priority to participation of local people for keeping environment clean. They have not been included in most of the planning and implementation process related to river environment. Further, the programs being developed for river environment conservation were sporadic and have no continuity and follow-ups.

Public perception towards the local authorities was not so positive. On the other hand, lack of space for surface disposal facility and proper implementation of existing environmental laws, no legal framework and guidelines for proper waste management and no strict land use/land cover zoning policy coupled with insufficient infrastructure were some of constraints faced by the local public institutions. These findings would be useful to local agencies for future planning and management of river environment in other cities and towns of Nepal.

\section{References}

Baidya, H R (2005), Kathmandu valley environment revival, The Earth Preservation. Vol 2: 107111.

Basnet, P S (2005), Solid waste dumping along banks of the Bagmati River in Kathmandu and its impact on water quality of Bagmati. The Earth Preservation. Vol 2, Issue 2. 
Khatri, T B (1986), Study of Water Pollution of River Bagmati and Bishnumati in Kathmandu Valley. Master's Thesis, Central Department of Zoology, Tribhuvan University, Kirtipur, Nepal.

MOPE (1999). Environmental Planning and Management of Kathmandu Valley. Kathmandu: Ministry of Population and Environment.

Shakya, B (2007), Rain, River and Ground water quality in Kathmandu Valley. In: Mutschler R, Shrestha P and Chitrakar Y (eds.), Proceeding of International Symposium on Community-led Management of River Environment.194-203.

Shrestha, S (2008), Cultural Habits and Spatial Pattern of River Bank Environment in Urban Kathmandu: A case study along Bishnumati River Bank. Research Report. Kathmandu: University Grant Commission, Bhaktapur.

Tuladhar, D (2006), Environment Change along the Bagmati River in Kathmandu Valley. Master's Thesis, Central Department of Geography, Tribhuvan University, Kirtipur, Nepal.

UNEP (2002), Status of Environment 2001, Nepal. Kathmandu: UNEP, MOPE, ESACEP, ICIMOD and NORAD. 